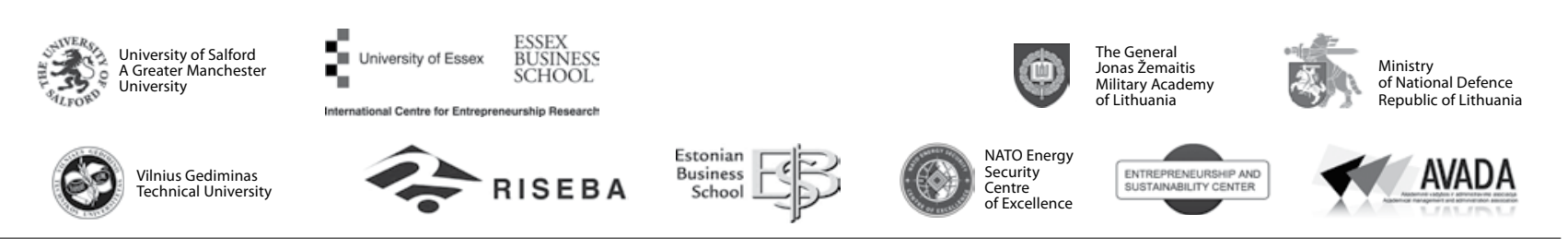

\author{
JOURNAL OF SECURITY AND SUSTAINABILITY ISSUES \\ ISSN 2029-7017 print/ISSN 2029-7025 online \\ 2017 June Volume 6 Number 4 \\ http://doi.org/10.9770/jssi.2017.6.4(10)
}

\title{
TOWARDS SUSTAINABLE ORGANIZATION: INTEGRATIVE CONCEPTUAL MODEL FOR EMPLOYER BRANDING
}

\author{
Rita Bendaravičienė \\ Vytautas Magnus University, K. Donelaičio str. 58, LT-44248, Kaunas, Lithuania \\ E-mail: rita.bendaraviciene@vdu.lt
}

Received 11 January 2016; accepted 15 May 2016

\begin{abstract}
Despite the great popularity of employer branding among practitioners, research in the field still poses a number of critical questions and issues for management scholars. Given an implicit but undeveloped employer branding theory and its conceptual ambiguity, this paper reviews terminology of the phenomenon, clarifying the essence of employer branding from both marketing and management perspectives. Employer branding process is investigated through comparative analysis of available employer branding frameworks and, overcoming their limitations, an integrative conceptual employer branding model is developed and an analytical three-step process for employer brand development is suggested as a means towards sustainable organization.
\end{abstract}

Keywords: employer brand, brand identity, employer branding, employer brand development, employer branding framework, employer branding proposition, organizational attractiveness

Reference to this paper should be made as follows: Bendaravičienė, R. 2017. Towards sustainable organization: integrative conceptual model for employer branding, Journal of Security and Sustainability Issues 6(4): 649-662. http://doi.org/10.9770/jssi.2017.6.4(10)

JEL Classifications: M12; M30

\section{Introduction}

Employer branding as an influential approach and a new discourse of human resource management (Martin et $a l ., 2005)$ has received much attention in practitioner world and has prompted a steady stream of articles, books (Barrow and Mosley, 2011; Sartain and Schumann, 2006), blogs and investigative pieces, as well as a rapid growth of consultancy firms and services, devoted to the topic. The literature examines theoretical foundations and conceptual framework of employer branding (Ambler and Barrow, 1996; Backhaus and Tikoo, 2004; Edwards, 2010; Lievens et al., 2007; Moroko and Uncles, 2009; Mosley, 2007; Wilden et al, 2010; Martin et al., 2005), analyzing its dimensionality (Hillebrandt and Ivens, 2013; Berthon et al., 2005; Baroniené, Žirgutis 2016; Raudeliūnienè et al.; 2016), exploring premises of attraction to an employer (Highhouse et al, 2007; Highhouse et al, 2003; Devendorf and Highhouse, 2008; Schreurs et al, 2009; Zaveri and Mulye, 2010; Nadler et al., 2010; Ehrhart and Ziegert, 2005; Lievens et al, 2001; Lievens, 2007; Lievens and Highhouse, 2003; Yu, 2014; Kausel and Slaughter, 2011; Lievens et al, 2005; Turban, 2001; Jiang and Iles, 2011; Shahzad et al., 2011; Prakapavičiūtè, Korsakienè 2016), and investigates specific aspects of the phenomenon, such as positioning (Sartain, 2005; Sivertzen et al, 2013; Kroustalis and Meade, 2007), employer branding outcomes (Davies, 2008; Cable and Edwards, 2004; Fulmer et al, 2003; Mosley, 2007), effects of corporate social performance (Turban and Greening, 1997; Albinger and Freeman, 2000), and characteristics of successful employer brands (Moroko and Uncles, 2008). 
Nevertheless, more research is still needed on employer branding as there are more questions than answers and little empirical data as well as serious, independent studies on particular aspects of employer branding are available (Jenner and Taylor, 2007; Martin, 2007). The undeveloped employer branding theory, its conceptual ambiguity (Backhaus and Tikoo, 2004; Moroko and Uncles, 2008, Martin, 2007; Edwards, 2010, Lievens, 2007) and the lack of knowledge on how organizations should develop and implement effective employer branding (Backhaus and Tikoo, 2004; Edwards, 2010) is particularly regrettable, since being a great workplace creates reputation which attracts talents, reduces turnover, fosters creativity and innovation of employees, sets a high-quality standard on culture, increases resistance against downturns or market shocks, provides higher levels of customer satisfaction and loyalty and, eventually, helps an organization to outperform its competitors and achieve financial success (Great Place to Work, 2014). Moreover, motivation, which is provided by the good workplace ,can be viewed as a prognostic factor of sustainability/unsustainability of development of the company as a whole“ (Guseva et al. 2016:145). On the larger scale, innovation and "the development of human capital are the most important indicators that are creating the competitiveness and sustainability of the country“ (Aleksejeva, 2016: 354). Therefore, it is the particular ambition of this paper to elaborate on the terminology of employer branding construct and to explore a framework for employer brand development strengthening its conceptual foundations and providing with the analytical framewok for its practical application.

\section{Defining the employer brand}

Employer branding was first coined by Ambler and Barrow (1996: 187) and defined as "the package of functional, economic and psychological benefits provided by employment, and identified with the employing company". Employer branding is also defined as "a targeted, long term strategy to manage the awareness and perceptions of employees, potential employees, and related stakeholders with regards to a particular firm" (Sullivan, 2004: para 1). Furthermore, employer branding "represents organizations' efforts to communicate to internal and external audiences what makes it both desirable and different as an employer" (Jenner and Taylor, 2007: 7). As Rosethorn and Mensink (2007: 6) assert, "employer branding is not a project or a programme. Nor is it a rush to freshen up your recruitment advertising. It's a way of business life. Understanding what engages people and being clear about what an organization offers and does not, means that you are more likely to recruit and therefore retain the right people."

Still and all, the broad but non-finite range of available partially overlapping definitions of employer brand and employer branding, presented in Table 1, displays the existing confusion and profusion of terminology in the employer branding literature.

Table 1. Definitions of employer brand and employer branding

\begin{tabular}{|l|c|}
\hline \multicolumn{1}{|c|}{ Definitions } & Source \\
\hline $\begin{array}{l}\text { "The package of functional, economic and psychological benefits provided by employment and } \\
\text { identified with the employing company". }\end{array}$ & $\begin{array}{c}\text { Ambler and Barrow } \\
\text { (1996: 187) }\end{array}$ \\
\hline $\begin{array}{l}\text { "How a business builds and packages its identity, from its origins and values, what it promises to deliver } \\
\text { to emotionally connect employees so that they in turn deliver what the business promises to customers". }\end{array}$ & $\begin{array}{c}\text { Sartain and Shuman } \\
\text { (2006: vi) }\end{array}$ \\
\hline $\begin{array}{l}\text { "An employer brand is a set of attributes and qualities - often intangible - that makes an organization } \\
\text { distinctive, promises a particular kind of employment experience, and appeals to those people who will } \\
\text { thrive and perform to their best in its culture". }\end{array}$ & $\begin{array}{c}\text { Co Personnel and } \\
\text { Development (2007) }\end{array}$ \\
\hline $\begin{array}{l}\text { "Represents organizations' efforts to communicate to internal and external audiences what makes it both } \\
\text { desirable and different as an employer". }\end{array}$ & $\begin{array}{c}\text { Jenner and Taylor } \\
\text { (2007: 7) }\end{array}$ \\
\hline $\begin{array}{l}\text { "A targeted, long-term strategy to manage the awareness and perceptions of employees, potential } \\
\text { employees, and related stakeholders with regards to a particular firm" }\end{array}$ & $\begin{array}{c}\text { Sullivan } \\
\text { (2004: para 1) }\end{array}$ \\
\hline $\begin{array}{l}\text { "Employer branding is an activity where principles of marketing, in particular the "science of } \\
\text { branding", are applied to HR activities in relation to current and potential employees". }\end{array}$ & Edwards (2010: 6) \\
\hline $\begin{array}{l}\text { "The employer brand establishes the identity of the firm as an employer. It encompasses the firm's } \\
\text { values, systems, policies, and behaviors toward the objectives of attracting, motivating, and retaining } \\
\text { the firm's current and potential employees". }\end{array}$ & $\begin{array}{c}\text { The Conference Board } \\
\text { (2001: 10) }\end{array}$ \\
\hline
\end{tabular}




\begin{tabular}{|l|c|}
\hline $\begin{array}{l}\text {,The term employer branding suggests differentiation of a firm's characteristics as an employer from } \\
\text { those of its competitors, the employment brand highlights the unique aspects of the firm's employment } \\
\text { offerings or environment". } \\
\text { Employer branding is "the process of building identifiable and unique employer identity“. }\end{array}$ & $\begin{array}{c}\text { Backhaus and Tikoo } \\
\text { (2004: 502) }\end{array}$ \\
\hline $\begin{array}{l}\text { Employer branding involves managing a "company's image as seen through the eyes of its associates } \\
\text { and potential hires". }\end{array}$ & $\begin{array}{c}\text { Martin and Beaumont } \\
\text { (2003: 15) }\end{array}$ \\
\hline $\begin{array}{l}\text { "The image of your organization as a 'great place to work' in the mind of current employees and key } \\
\text { stakeholders in the external market (active and passive candidates, clients, customers and other key } \\
\text { stakeholders). The art and science of employer branding is therefore concerned with the attraction, } \\
\text { engagement and retention initiatives targeted at enhancing your company's employer brand". }\end{array}$ & $\begin{array}{c}\text { Minchington } \\
\text { (2011a: 28) }\end{array}$ \\
\hline $\begin{array}{l}\text { "An employer brand is the sum of all the characteristics and distinguishable features that prospective } \\
\text { candidates and current employees perceive about an organization's employment experience" }\end{array}$ & $\begin{array}{c}\text { Versant Works } \\
\text { (n.d.: 2) }\end{array}$ \\
\hline $\begin{array}{l}\text { Employer branding "represents a further extension of branding theory and research, involving efforts to } \\
\text { communicate to existing and prospective staff that the organization is a desirable place to work, creating } \\
\text { compelling, distinctive employee value proposition". }\end{array}$ & $\begin{array}{l}\text { Jiang and Iles, } \\
\text { (2011:98) }\end{array}$ \\
\hline
\end{tabular}

Employer branding has emerged as a viable conceptual framework unifying separate disciplines of human resource management and brand marketing and applying brand management techniques and brand thinking to employment context (Ambler and Barrow, 1996). Therefore, clarifying the essence of employer branding it should be seen from both management and marketing perspectives.

In marketing terms brand is "a name, symbol, logo, design or image, or any combination of these, which is designed to identify the product or service" (Kotler et al. 2009: 425) and to represent the consumer's experience with an organization, product or services. A brand is intended to differentiate products, services, persons or places and distinguish them from those of competitors. According to Kotler et al. (2009), a brand can also be viewed as a holistic, emotional and intangible experience and be strong enough to "evoke feelings and belongings, love and affection" (p. 426).

As suggested by Aaker (2012) and summarized by Esch (2010; see Figure 1) brand can be seen from four perspectives: 1) brand as a product; 2) brand as an organization; 3) brand as a person, and 4) brand as a symbol, altogether forming a brand identity. The brand as a product encompasses product-related associations and product-related attributes providing functional and emotional benefits. Product-related attributes create a value proposition, offering unique or better quality and value features and services. Brand as a product may be associated with use occasion, typical users or linked to a country or region. The brand as an organization perspective is related to organizational attributes, such as quality or innovativeness that are based on organizational values, culture, programs and people. The brand as a person consists of a brand personality concept and customerbrand relationship construct. Eventually, brand as a symbol includes audio and visual images, metaphors and brand heritage. All four perspectives should be considered in order to build strong brands; however, for some of them only one perspective will be appropriate.

Brand identity, similarly as a person's identity, provides direction, purpose and meaning for the brand and includes a core and extended identity, where core identity embraces the central, timeless essence of the brand; whereas the extended identity "includes brand identity elements, organized into cohesive and meaningful groupings that provide texture and completeness" (Aaker, 2012:3). Brand essence can focus on what the brand is, or a rational appeal that emphasizes functional benefits (e.g., Xerox: "The digital document company"), or it can focus on what the brand does to its customers, i.e., emotional benefits, such as Microsoft: "Help people realize their potential" (Aaker and Joachimsthaler, 2009: 48-49). 
Fig. 1. Brand identity model

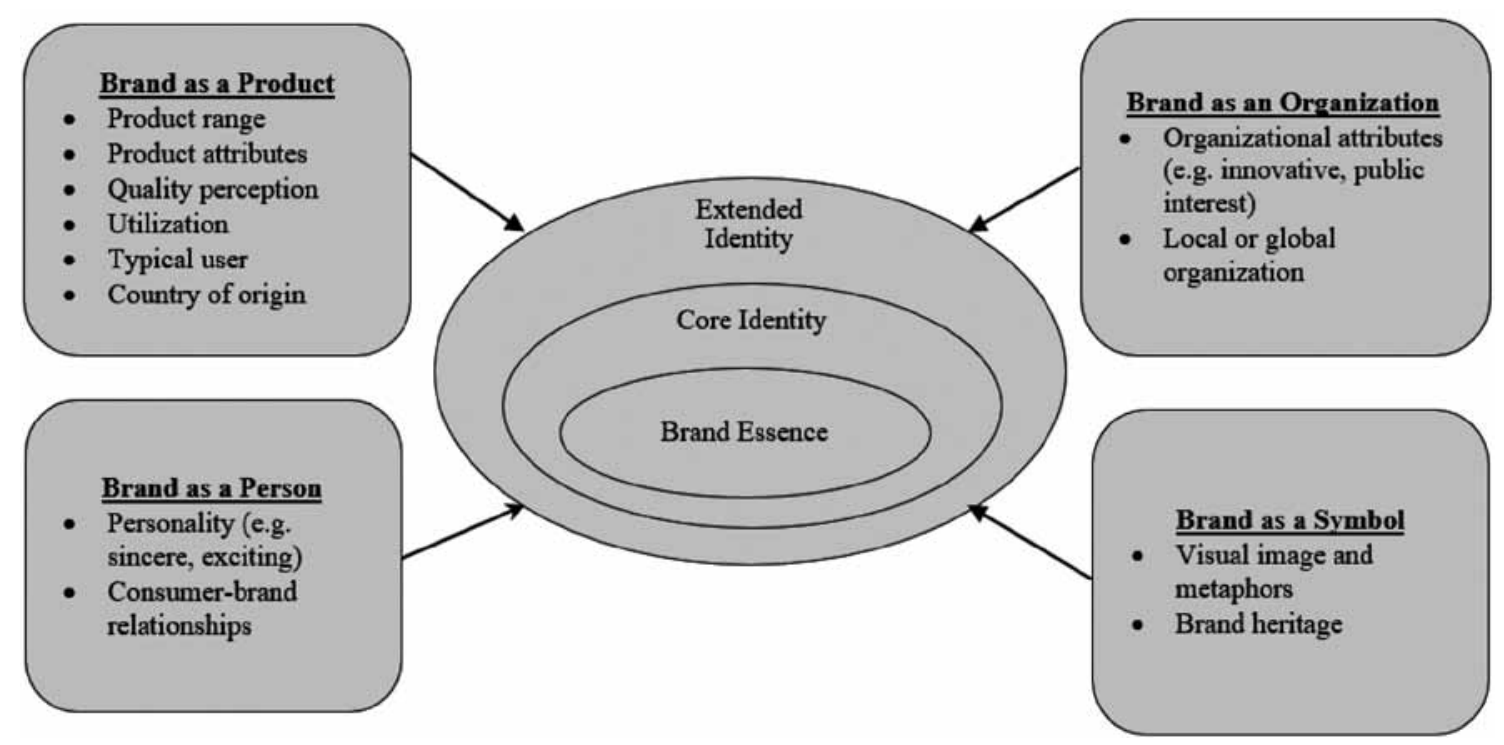

Source: Esch (2010: 96)

A useful way to think about the brand is offered by Esch et al. (2006: 63) with the Brand Steering Wheel (see Figure 2) which is an instrument used to find out how the brand is seen by customers and to create a corresponding brand identity. The Brand Steering Wheel comprises the left objective part including brand competence, brand benefits, and the reason why, and the right subjective or emotional part including brand tonality and brand picture. Brand competence asks company "Who are we" and is concerned with organization's history and duration in the market, origin of organization, its role in the market and central brand assets. Brand benefits (and the reason why) distinguish between brand attributes (which properties do we have), i.e. attributes of products and services, and characteristics of the company, and value proposition (what do we offer) of the brand functional and psycho-social benefits. Brand tonality refers to emotions and feelings connected to the brand, its personality traits, brand experiences and brand relations. Finally, brand picture reflects all perceptible modalities - specific visual, haptic, olfactory, acoustic and gustatory impressions as an effect of brand awareness and image.

Evidently, these four pillars of brand identity can be easily associated with the mind-set of Aaker (2012), where brand competence can be linked to brand as organization, brand benefits can be linked to brand as a product, brand tonality can be related to brand as a person, and brand picture can be related to brand as a symbol.

Fig. 2. Brand Steering Wheel

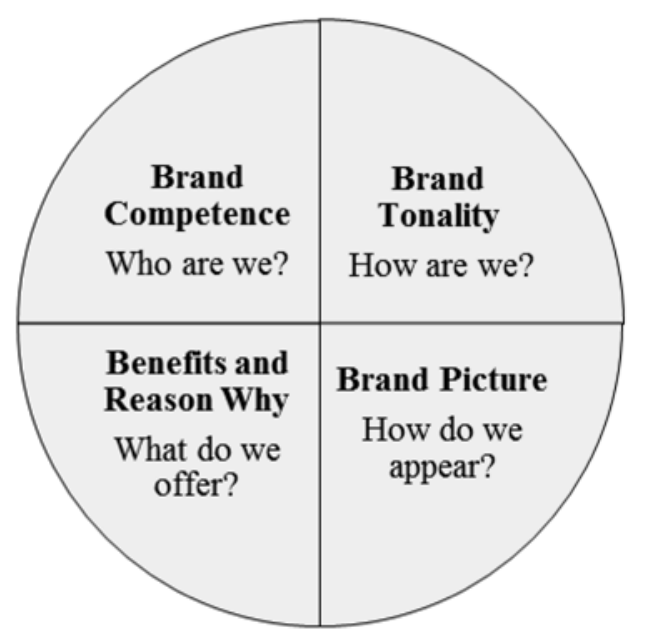


Transferring this holistic approach to the context of employer branding, it can be noticed that employer brand could be also perceived as a product, offering "functional, economic and psychological benefits provided by employment" (Ambler and Barrow, 1996: 187), as an organization, encompassing "the firm's values, systems, policies and behaviors" (The Conference Board, 2001: 10), as a symbol involving "the image of ... organization as 'great place to work"' (Minchington, 2011a: 28), or as a person with intangible qualities appealing to and emotionally connecting employees (Sartain and Shuman, 2006: vi; Chartered Institute of Personnel and Development, 2007).

Putting the focus on the brand as a product or, otherwise, on the brand attributes and value proposition, existing and potential employees will be seen as customers, and unique and particular employment experience will be conceived as a branded product (Edwards, 2010; Moroko and Uncles, 2008). Respectively, employer branding will suggest "the differentiation of a firm's characteristics as an employer from those of its competitors" (Backhaus and Tikoo, 2004: 502) and imply that employer experience is an organization-specific employment offering determining organizational attractiveness.

As Table 2 demonstrates, similarly, extending on the assertion from marketing literature that brands play functional, rational and symbolic roles related to the performance or representation of product or service (Kotler et al., 2009), employment experience will therefore encompass the totality of tangible and intangible reward features provided to and valued by employees, such as challenging, stimulating and fulfilling work environment, competitive compensation and benefits, engagement with and positive regard for an employer of choice, cumulatively constituting a compelling employment value proposition (Simmons, 2009).

Table 2. Benefits of aligning external and internal brands

\begin{tabular}{lcl}
\hline \multicolumn{1}{c}{ External brand (customers) } & $\begin{array}{c}\text { Corporate } \\
\text { brand } \\
\text { Benefits }\end{array}$ & Internal brand (employees) \\
\hline High quality goods and services & Functional & Challenging, stimulating and fulfilling work environment \\
\hline Excellent value for money & Economic & Competitive compensation and benefits \\
\hline $\begin{array}{l}\text { Premium products, preferred supplier } \\
\text { Affinity with organization values and } \\
\text { belief in its societal contribution }\end{array}$ & Psychological & Employer of choice, engagement with the organization \\
\hline $\begin{array}{l}\text { A compelling product value proposition } \\
\text { to current and prospective customers }\end{array}$ & Cumulative & $\begin{array}{l}\text { Affinity with organization values from perceived congruence of its ethical } \\
\text { dealings with employees, customers and wider society }\end{array}$ \\
\hline
\end{tabular}

Source: Simmons (2009: 686)

Summing it up, employer brand could be referred to as a set of particular employment experience attributes that makes an organization distinctive and attractive as an employer (to existing and potential employees). This definition could be visualized through a concentric circle model of employer brand as shown in Figure 3, where concentric circles indicate the catalytic outward process of employer brand development and suggest the coherence of its facets. 
Fig. 3. Concentric circle model of employer brand

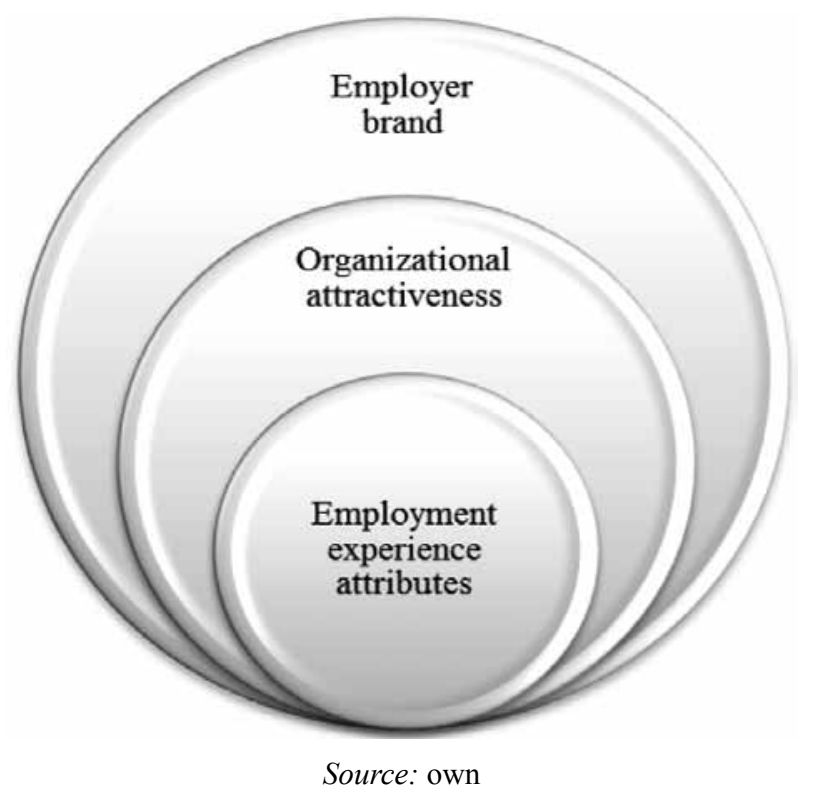

With this definition the emphasis is put on the internal perspective, i.e. building employer brand from the inside out: identifying and articulating the experience employees can expect - from training, performance management, and compensation to rewards, promotion and communication. This primarily means answering the fundamental question for the employee "What's in it for me?" if I work there and touches every dimension of the employee's relationship with the organization (Sartain and Schuman, 2006: 43).

\section{Employer brand development}

Illustrating the scope of concepts and contexts, covered by employer branding activities it is useful to consider the 'bigger picture' as it is demonstrated by Minchington's (2012) employer branding eco-system (see Figure 4), providing with some basic insight into diversity of stakeholders and complexity of functions engaged in building strong employer brand. 
Fig. 4. Employer branding eco-system

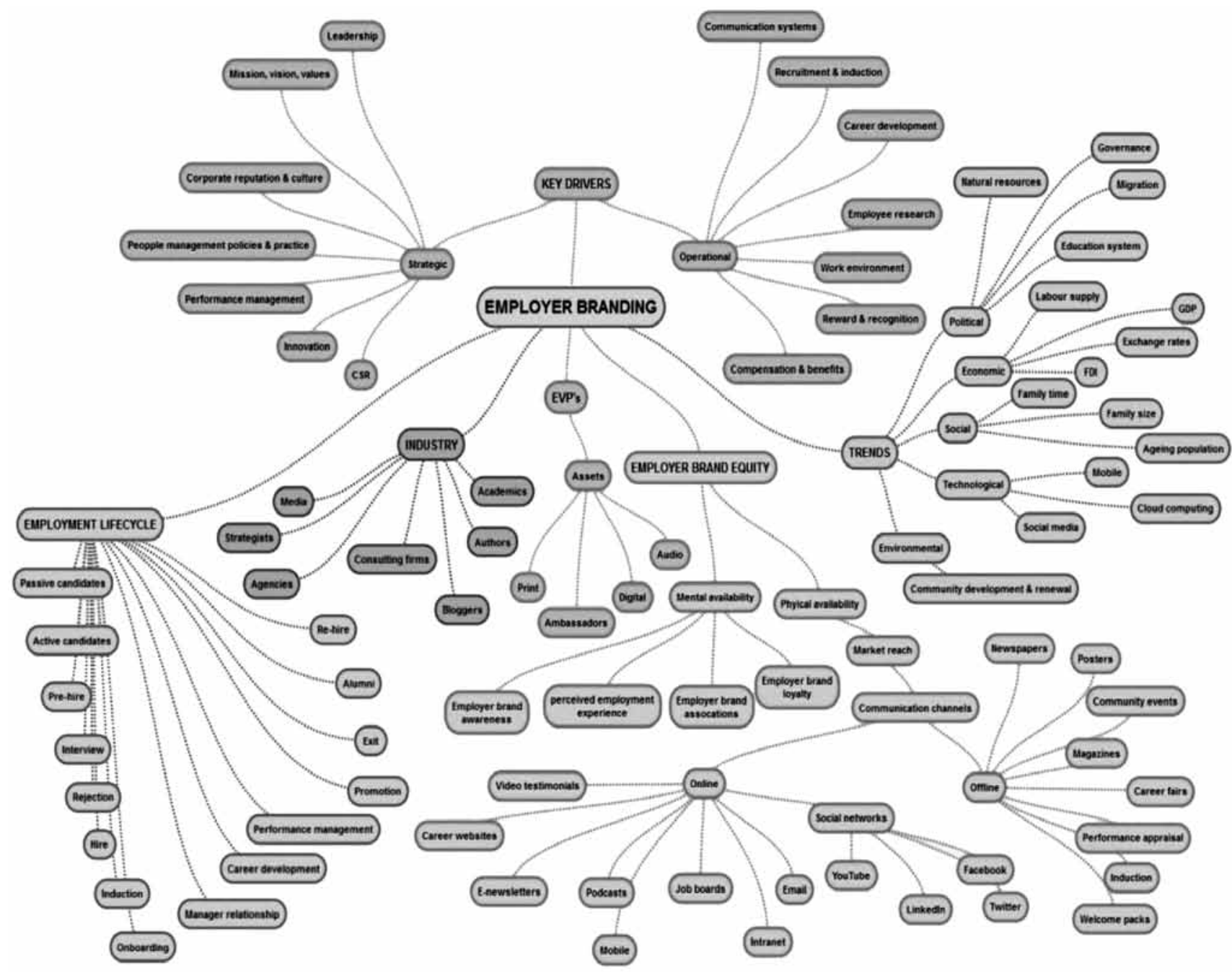

Source: Minchington (2012)

In their major study Backhaus and Tikoo (2004) presented a theoretical foundation and conceptual framework for employer branding, incorporating marketing and human resource concepts (see Figure 5). Authors suggest that employer branding creates two main assets - employer brand associations and employer brand loyalty. Employer brand associations affect brand image, which in turn enhances attraction to the company. Organizational culture and employer branding have a reciprocal relationship: employer branding reinforces and changes organizational culture, and organizational culture impacts employer branding. Backhaus and Tikoo (2004) see organizational identity as the attitudinal contributor to employer brand loyalty and as a successor of employer branding. Finally, employer brand loyalty is supposed to increase employee productivity. The authors conclude that employer branding is a useful framework for strategic human resource management and provides support for the organizational career management program. 
Fig. 5. Employer branding framework

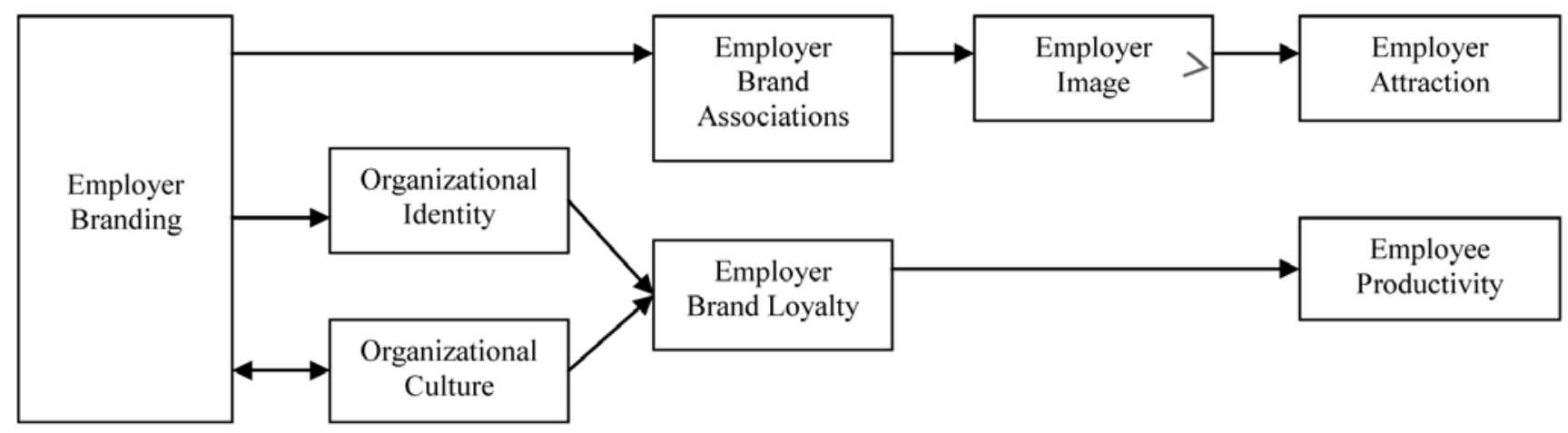

Source: Backhaus and Tikoo (2004:505)

As Figure 6 shows, the conceptual framework of employer branding developed by Martin (2007) suggests that employer branding begins with the creation of an employer brand image, encompassing the organization's package of functional, economic and psychological benefits. Two key drivers of employer brand image are corporate identity and organizational identity (in contrast to Backhaus and Tikoo, 2004) that are conceived as products of organizational culture, i.e. "hidden values, assumptions and beliefs that define 'the way we do things around here"" (Ibid, p.19). Corporate identity there is defined as a posture of organization's mission, strategies and culture, expressed through logos, architecture and communication of 'what it is', while organizational identity refers to organizational self-concept of 'who we are', "revealed in its shared knowledge, beliefs, language and behaviors" (Ibid). Further, in this model, employer brand reputation stands for the biographical account of organization instrumental and symbolic attributes offered to and perceived by potential and existing employees. According to Martin (2007), positive employer brand reputation should help attract talented applicants, ensure employees' identification with the organization and, eventually, result in desired organizational performance, in turn enriching organizational identity.

Fig. 6. Employer branding framework

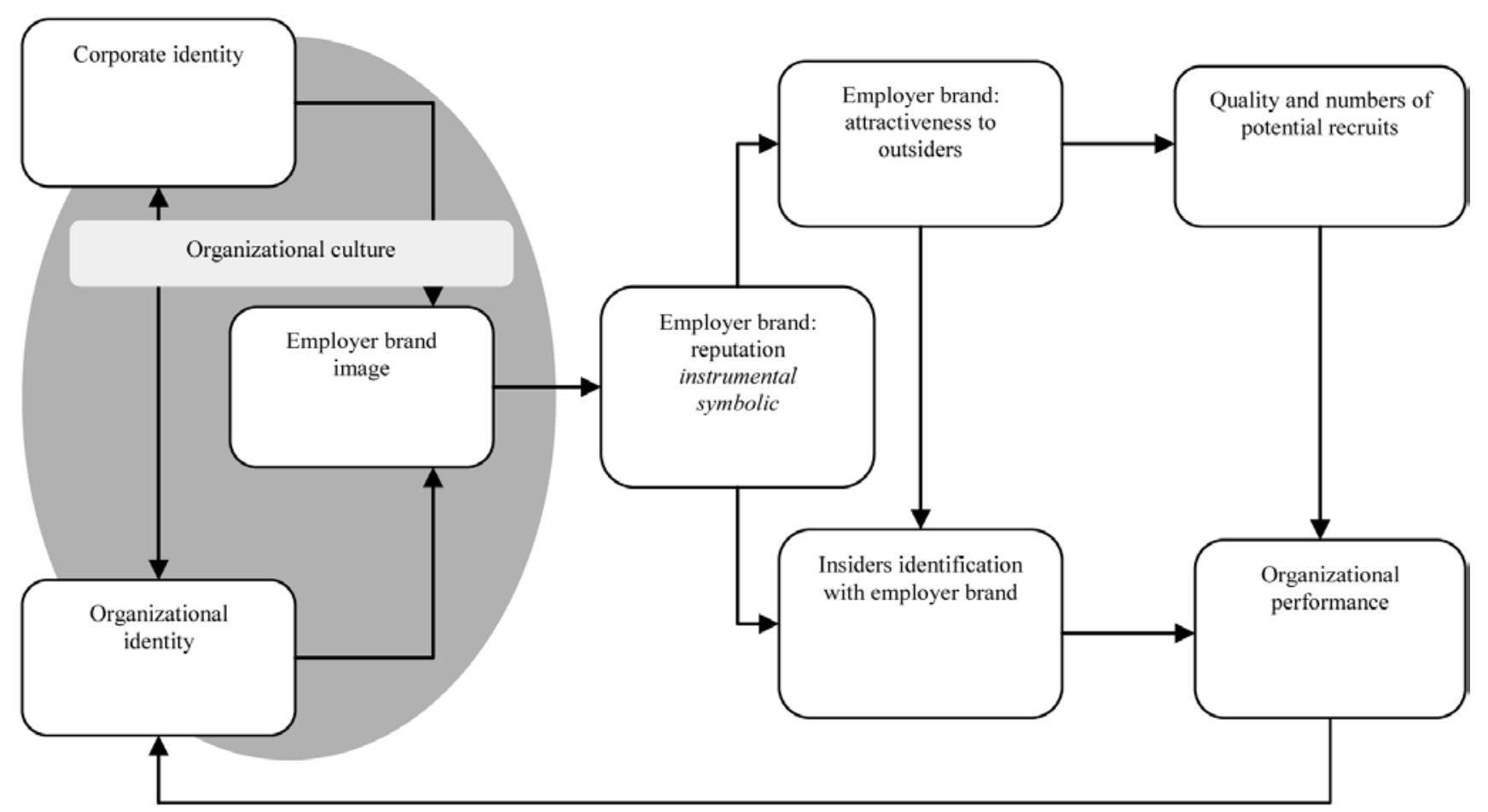


Jiang and Iles (2011) followed Backhaus and Tikoo (2004) complementing their model by elaboration on the relationship between organizational attractiveness and employee-based brand equity. First, as mentioned earlier, a broader perspective was adapted to understanding of organizational attractiveness distinguishing between internal attractiveness encouraging existing employees to stay with the company, and external attractiveness encouraging potential employees to apply. Next, intentions to accept a job or stay with the company were analyzed as consequences of organizational attractiveness, which in turn were considered as a consequence of employee-based brand equity. Employee-based brand equity therein is referred as employer brand equity as perceived by employees and assessed by five dimensions: economic value, social value, development value, interest value and brand trust. Employer brand equity is defined as a value provided by employment to existing and potential employees. Interestingly, Wilden et al. (2010) have found that employer attractiveness is an antecedent of employee-based brand equity.

Although being fairly comprehensive, the above models still lack some integrity, depth and rigour, and leave unanswered questions and questionable assumptions. Therefore, incorporating the conceptual employer branding frameworks proposed by Martin (2007), Backhaus and Tikoo (2004), Model of Employer Brand Equity formed by B. Minchington (2011a) and encompassing the foregoing theoretical considerations an integrative employer branding model is developed here and presented in Figure 7 for further elaboration.

Fig. 7. Integrative conceptual employer branding model

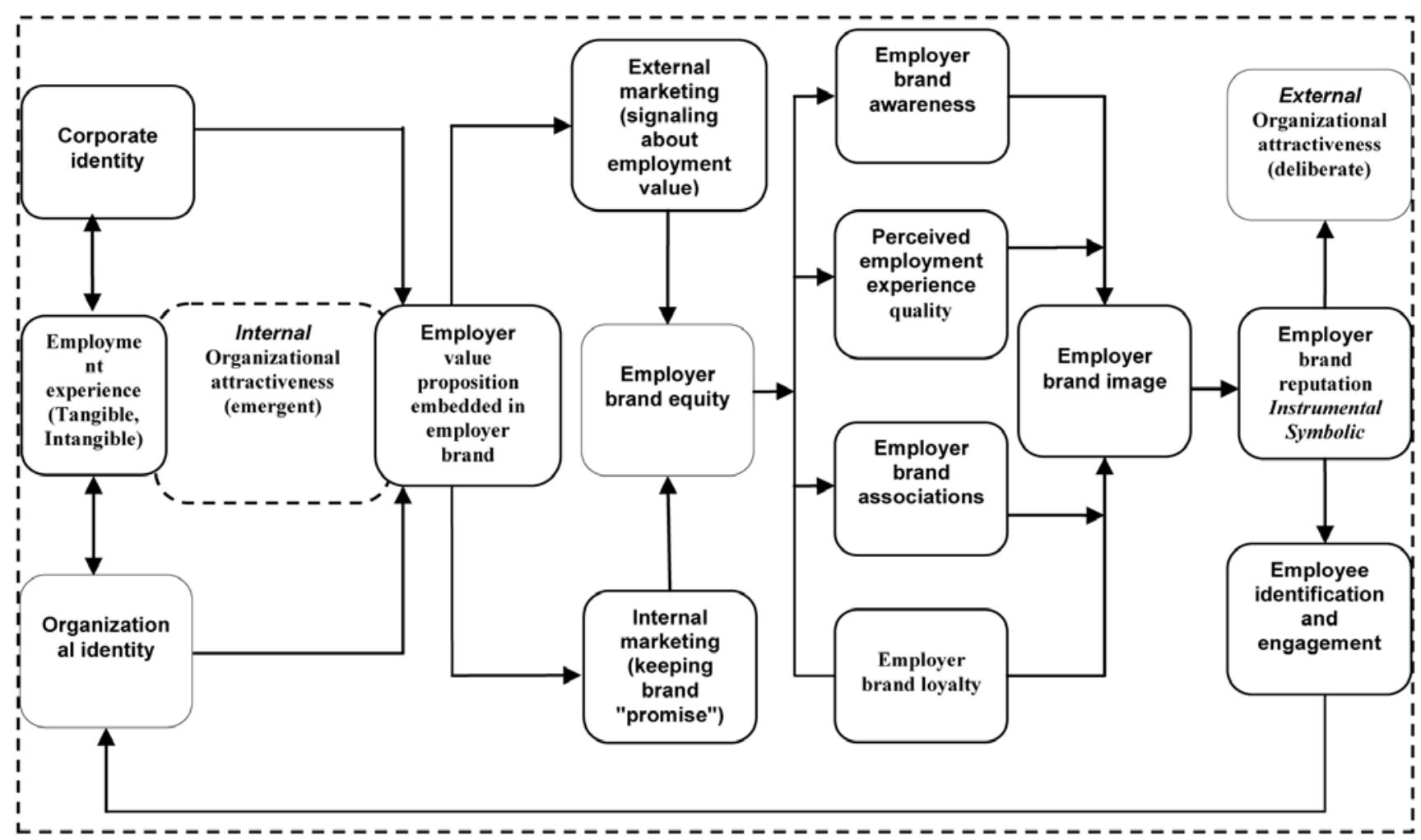

Source: own

The model suggests that employer branding is a circular process that begins with the creation of an employer value proposition. Employer value proposition or otherwise referred to as an employer brand proposition (Barrow and Mosley, 2011) or brand promise (Martin, 2007; Backhaus and Tikoo, 2004) is a central message to be embedded in employer brand about unique employment experience and particular value offered by the company to the existing and potential employees (Backhaus and Tikoo, 2004; Edwards, 2010). For example, Stanford Project on Emerging Companies (SPEC) while explaining determinants and diversity of employment relations and blueprints has elaborated on three types of attachment (Work, Love, Money), three types of selection (Skills, Potential, Fit) and four types of coordination/control (Peer/Cultural, Professional, Formal and 
Direct), finally clustering into five basic employment models (Engineering, Star, Commitment, Bureaucracy and Autocracy). As Hsu and Hannan, (2005) have put it "firms' identities in the labor market are expected to be wrapped up with these employment systems and with the cultures they create". It should be noted and stressed here that employment experience or employment offering is organization specific and encompasses a "complex array of features" (Edwards, 2010).

Ambler and Barrow (1996) have suggested that employer brand offers employees: (1) developmental and useful activities (virtuositas, or functional benefits); (2) material or monetary rewards (raritas, or economic benefits); and (3) feelings such as belonging, direction and purpose (complacibilitas, or psychological benefits). Drawing from psychological contract literature (Martin and Hetrick, 2006), employment experience can be also differentiated on ideological benefits, as providing employees the self-fulfillment through "doing good". As Barrow and Mosley (2011: 123) state, "the proposition statement should try to capture the most compelling advantage offered by the employer", such as trust and respect, an interesting job, the opportunity to get on, and a boss who supports you in Tesco; or fair and equitable pay, coaching and development, effective resource management, and pride and belief in values of organization in Building Society; or possibility to have a great start, work/life balance, to learn and grow, to be in the know, to make a positive impact, to be recognized, to share rewards and to share great ideas in Compass Group.

Furthermore, as Edwards (2010: 7) explicitly argues, "a central element to employer branding involves the identification of elements of the character of the organization itself; features such as the organization's key values and the guiding principles underlying how it operates as a collective entity". To put it in another way, in order to create successful employer value proposition corporate identity and organizational identity should be researched, understood and, ideally, incorporated.

The concept of corporate identity, even though grown out from logos and outward presentation of a company to external audiences, "is not merely a projected image in the form of visual design and communication, but is fundamentally concerned with 'what the organization is' encompassing the strategies and culture specific to the organization in particular" (Cornelissen et al., 2007: S7).

Meanwhile organizational identity can be conceived "as the collective attitude about who the company is as a group" (Backhaus and Tikoo, 2004: 509); it embraces the organizational 'core' and encompasses "key values and the guiding principles underlying how it operates as a collective entity" (Edwards, 2010: 7). Organizational identity reflects organization's purpose and philosophy - what is perceived as central, distinctive and enduring to a focal organization by internal (and external) audiences (Margolis and Hansen, 2002; Lievens et al., 2007). Organizational identity can also be seen as "as an interpretative system, or as a set of shared cognitions, or as shared language and behaviors" (Cornelissen et al., 2007: S6). In this vein, organizational identity can be understood as a 'single organism' or 'human being' with inherent identity of 'who am I as an organization?', or as cognitive self-representation adopted by organizational members, or as a construct of organizational rhetoric, myths, stories and culturally patterned practices. Davies and Chun (2002) offer to define identity as an internal dimension which reflects the employees' feelings and comprehension of the organization by answering the questions "who are we?" and "how do we see ourselves?". These unique and timeless features of the organization are seen as fundamental by its members (Puusa and Tolvanen, 2006).

Nevertheless, organizational identity is regarded as one on the prime inputs of employer value proposition and, accordingly, of the whole employer branding, the research streams focusing on organizational identity and employer branding have evolved and partly remained apart with few unifying attempts (e.g., Lievens et al, 2007). However, discovery and research of organizational identity allows understanding the common organizational consciousness; it reveals the shared perception of 'who we are', enables uncovering the employment experience it embraces and identifying the features that make organization attractive as an employer. The latter phenomenon needs some more consideration. It should be noticed that organization, even though doing nothing at the area of employer branding nevertheless has its particular employment relations and practices and will definitely have a positive or negative reputation as an employer and will be perceived as an attractive or 
poor place to work. This perspective unfolds a particular feature of organizational attractiveness that is unconsciousness and deliberateness. Employer branding is aimed at creating an employer of choice, i.e. deliberate employer attractiveness, while organizational attractiveness stemming from perceived employment experience is by nature an emergent phenomenon.

Another insight follows from the notion of organizational attractiveness as an employer that is referred to as "the envisioned benefits that a potential employee sees in working for a specific organization" (Berthon et al., 2005: 156) or the degree to which potential applicants and current employees favorably perceive organizations as places to work (Jiang \& Iles, 2011). It suggests that organizational or employer's attractiveness is a two-dimensional construct, where internal attractiveness expresses perceptions of existing employees and external attractiveness perceptions of potential applicants. It is worth mentioning that it is pretty a novel approach to organizational attractiveness, forasmuch as previous research has put an emphasis on the potential applicants perspective (e.g. Berthon et. al., 2005; Ehrhart and Ziegert, 2005, etc.) and very few studies have involved actual employees (e.g. Turban, 2001; Lievens et al., 2007) which could help to explore an 'experienced' opinion and make an attempt to answer why individuals who were attracted and selected consequently retain. Admitting this limitation of organizational attractiveness research, scholars (Nadler et al.; 2010; Ehrhart and Ziegert, 2005; Jiang and Iles, 2011) argue for more studies examining perceptions of workforce population.

Moreover, "it is crucial to study identity and attractiveness together because organizations typically want to attract talent by developing an attractive employer image while at the same time ensuring that this image is consistent with employee's views of the identity of the organization" (Lievens et al., 2007: 46). An integrated view of corporate and organizational identity is also presented by van Riel and Balmer (1997), who state that corporate identity indicates "the way in which an organization's identity is revealed through behavior, communications, as well as through symbolism to internal and external audiences" (p. 341). Most significantly, as the authors argue, the alignment, transparency and consonance between organizational identity, corporate identity and, additionally, corporate reputation (the images of organization held by outsiders) should be achieved; otherwise the misalignment will result in employee disengagement, customer dissatisfaction and organizational decline (Cornelissen et al., 2007).

Consequently, as Barrow and Mosley (2011) suggest, starting with corporate vision or mission, or the "big idea' for organizations existence (corporate identity), proceeding with organizational values providing differentiation, further honestly and authentically describing the personality of organization (organizational identity) - serious, passionate, challenging or fun, and, finally, identifying the range of benefits that drive employee engagement (employment experience) should allow capturing particular attributes of organizational attractiveness and eventuate in a specific employer brand proposition and tailored employee value propositions. Furthermore, the authors state that employer brand proposition is an integral part of organization's core proposition along with customer brand proposition, and that they are closely interrelated: the strength of customer brand plays an important role in attracting the right people, and vice versa, a positive employer brand helps building and supporting the customer brand. Referring to employer brand proposition as a most compelling and common reason given for employees' commitment and loyalty to the organization, the authors claim that it should bring "focus and consistency to the employee's experience of the organization" (Barrow and Mosley, 2011: 117).

Further, internal and external employer brand marketing activities should desirably result in employer brand equity that is referred to as a four-dimensional construct of employer brand awareness (the level of knowledge people have about an organization's positive or negative employment characteristics), perceived employment experience quality (the association people have about working for an organization stemming from online, e.g., career website, and offline, e.g., word of mouth source), employer brand associations (thoughts, ideas, imagery, symbols, emotional and rational attributes an organization's name evokes) and brand loyalty, i.e. person's intentions to apply and accept the job as well as remain employed driven by the positive associations with the organization (Minchington, 2011a). Employer brand equity and particularly employer brand associations are 
the determinants of employer brand image (Minchington, 2011b). The employer brand image, as an autobiographical account of who it wants to be forms the employer brand reputation that is the biographical account of who it is perceived through instrumental and symbolic attributes (Martin, 2007). The employer brand image affects employer attractiveness to potential employees and strengthens organizational identification and engagement among existing employees, which in turn strengthens and enriches organizational identity.

\section{Discussion and conclusion}

In this paper the existing terminology of employer brand was summarized and, admitting its confusion, a definition of employer brand was developed defining it as a set of particular employment experience attributes that make organization distinctive and attractive as an employer. Employer branding process was investigated through comparative analysis of available employer branding frameworks and the integrative conceptual employer branding model was developed and comprehensively discussed. From a practical perspective, the model suggests a number of managerial implications and can be utilized by organizations for their employer brand development through a three-step process of 1) Extraction, i.e., internal research assessing organization's current employment environment and the nature of employment relations, and answering the question "Who am I"?; 2) Distillation and Contemplation, capturing the essence of organizational attractiveness as an employer and answering the current and potential employees "What's in it for me?"; and 3) Creation, Activation and Cultivation, constructing distinctive, authentic, energizing and compelling employer value proposition, deeply embedding it into organization's psyche and soma and living your employer brand (see Figure 8).

Fig. 8. Analytical three-step process for employer brand development

\section{STEPS}

\section{OBJECTIVES}

- What employment experience organization provides to its employees?
- What are employee work values, needs and expectations?
- How organization's employment experience quality is perceived and what are
the areas for improvement?
- What factors drive organizational attractiveness as an employer?
- How committed are employees to their organization?

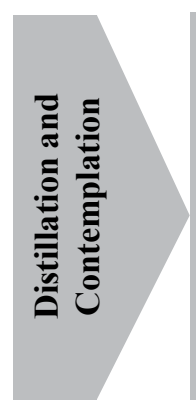

- What employment experience organization should be offering to its existing and potential employees?

- What kind of employees' organization is eager for?

- Where the uniqueness and distinctiveness of organization's attractiveness as an employer lies?

- What particular attributes and values of employment experience should be embedded in employer brand?

- 'Translate' the extracted and distilled knowledge into a compelling and authentic employer value proposition - brainstorm, outline and build organization's employer brand.

- Develop efficient target group-oriented employer brand strategies.

- Communicate organization's employer brand to external audiences

- Make and keep a promise to existing employees

- Nurture your employer brand and get employees connected and committed. 
The key idea behind the application of this framework is that every organization has an employer brand whether or not it has ever spent any time developing it. The Extraction stage is designed to diagnose the health of this unintentional employer brand and to find out whether it is working for or against organization (Sartain and Schuman, 2006). Accordingly, it should initiate the development of intentional employer brand that would derive from inside and enhance employee connection, commitment, contribution and engagement. Being very clear about where the organization is and where it wants to get to helps to introduce changes and eventually become an employer of choice. Organizations that would adopt the suggested employer brand development framework were enabled to strategically build their successful employer brands, introduce changes and establish their identity as an employer.

\section{References}

Aaker, D. A. (2012). Building strong brands. New York: Simon \& Schuster.

Aaker, D. A., \& Joachimsthaler, E. (2009). Brand leadership: building assets in an information economy. New York: Simon \& Schuster.

Albinger, H. S., \& Sarah J. Freeman, S. J. (2000). Corporate social performance and attractiveness as an employer to different job seeking populations. Journal of Business Ethics, 28(3), 243 - 253.

Aleksejeva, L. (2016). Country's competitiveness and sustainability: higher education impact. Journal of Security and Sustainability Issue, 5(3), http://dx.doi.org/10.9770/jssi.2016.5.3(4)

Ambler, T., \& Barrow, S. (1996). The employer brand. Journal of Brand Management, 4(3), 185-206.

Backhaus, K., \& Tikoo, S. (2004). Conceptualizing and researching employer branding. Career Development International, 9(5), 501-517.

Baronienè, L.; Žirgutis, V. (2016). Management decisions for sustainable development: medical software case study, Entrepreneurship and Sustainability Issues 4(2): 129-145. http://dx.doi.org/10.9770/jesi.2016.4.2(2)

Barrow, S., \& Mosley, R. (2011). The employer brand: bringing the best of brand management to people at work (Reprinted. ed.). Chichester [u.a.]: Wiley.

Berthon, P., Ewing, M., \& Hah, L. L. (2005). Captivating company: dimensions of attractiveness in employer branding. International Journal of Advertising, 24(2), 151-172.

Cable, D. M., \& Edwards, J. R. (2004). Complementary and supplementary fit: a theoretical and empirical integration. Journal of Applied Psychology, 89(5), 822-834.

Chartered Institute of Personnel and Development (2007). Employer branding: the latest fad or the future for HR. London: CIPD.

Cornelissen, J. P., Haslam, S. A., \& Balmer, J. M. (2007). Social identity, organizational identity and corporate identity: towards an integrated understanding of processes, patternings and products. British Journal of Management, 18(s1), S1-S16.

Davies, G. (2008). Employer branding and its influence on managers. European Journal of Marketing, 42(5/6), 667-681.

Davies, G., \& Chun, R. (2002). Gaps between the internal and external perceptions of the corporate brand. Corporate Reputation Review, 5(2/3), 144-158.

Devendorf, S. A., \& Highhouse, S. (2008). Applicant-employee similarity and attraction to an employer. Journal of Occupational and Organizational Psychology, 81(4), 607-617.

Edwards, M. R. (2010). An integrative review of employer branding and OB theory. Personnel Review, 39(1), 5-23.

Ehrhart, K. H. \& Ziegert, J. C. (2005). Why are individuals attracted to organizations? Journal of Management, 31(6), 901-919.

Esch, F. R. (2010). Strategie und Technik der Markenführung. $6^{\text {th }}$ Ed., Munich: Vahlen.

Esch, F. R., Kiss, G. \& Roth, S. (2006). Identität einer Corporate Brand erfassen und entwickeln, pp. 53-74, in: Esch, F. R., Tomczak, T.,

Kernstock, J. and Langner, T. (Ed.) (2006): Corporate Brand Management, Marken als Anker strategischer Führung von Unternehmen, 2nd Ed., Wiesbaden: Gabler Verlag. 
Fulmer, I. S., Gerhart, B., \& Scott, K. S. (2003). Are the 100 best better? An empirical investigation of the relationship between being a "great place to work" and firm performance. Personnel Psychology, 56(4), 965-993.

Great Place to Work (2014). What is a Great Workplace?. Retrieved from http://www.greatplacetowork.com/our-approach/what-is-agreat-workplace

Guseva, S., Dombrovskis, V., Čapulis. S. \& Lukash, S. (2016). Country’s competitiveness and sustainability: higher education impact. Journal of Security and Sustainability Issues, 6(1) http://dx.doi.org/10.9770/jssi.2016.6.1(11)

Highhouse, S., Lievens, F., \& Sinar, E. F. (2003). Measuring attraction to organizations. Educational and Psychological Measurement, 63(6), 986-1001.

Highhouse, S., Thornbury, E. E., \& Little, I. S. (2007). Social-identity functions of attraction to organizations. Organizational Behavior and Human Decision Processes, 103(1), 134-146.

Hillebrandt, I. \& Ivens, B. S. (2013). Scale Development in Employer Branding. Impulse für die Markenpraxis und Markenforschung, Tagungsband der internationalen Konferenz „DerMarkentag 2011“, Springer Fachmedien Wiesbaden, 65-86.

Hsu, G., \& Hannan, M. T. (2005). Identities, genres, and organizational forms. Organization Science, 16(5), 474-490.

Jenner, S. \& Taylor, S. (2007). Employer branding - fad or the future for HR?. Employer branding: the latest fad or the future for HR?. London: CIPD.

Jiang, T., \& Iles, P. (2011). Employer-brand equity, organizational attractiveness and talent management in the Zhejiang private sector, China. Journal of Technology Management in China, 6(1), 97-110.

Kausel, E. E., \& Slaughter, J. E. (2011). Narrow personality traits and organizational attraction: Evidence for the complementary hypothesis. Organizational Behavior and Human Decision Processes, 114, 3-14.

Kotler, P., Keller, K. L., Brady, M., Goodman, M \& Hansen, T. (2009). Marketing Management. New Jersey: Pearson Education.

Kroustalis, C. M. \& Meade, A. W. (2007). Portraying an Organization's Culture through Properties of a Recruitment Website. Paper presented at the 22nd Annual Meeting of the Society for Industrial and Organizational Psychology, New York, Retrieved from http://www4.ncsu.edu/ awmeade/Links/Papers/Internet_Recruit(SIOP07).pdf

Lievens, F. (2007). Employer branding in the Belgian army: the importance of instrumental and symbolic beliefs for potential applicants, actual applicants, and military employees. Human Resource Management, 46(1), 51-69.

Lievens, F., \& Highhouse, S. (2003). The relation of instrumental and symbolic attributes to a company's attractiveness as an employer. Personnel Psychology, 56(1), 75-102.

Lievens, F., Decaesteker, C., Coetsier, P., \& Geirnaert, J. (2001). Organizational attractiveness for prospective applicants: A personorganization fit perspective. Applied Psychology: An International Review, 50, 576-587.

Lievens, F., Hoye, G. V., \& Anseel, F. (2007). Organizational identity and employer image: towards a unifying framework. British Journal of Management, 18(s1), S45-S59.

Lievens, F., Hoye, G. V., \& Schreurs, B. (2005). Examining the relationship between employer knowledge dimensions and organizational attractiveness: An application in a military context. Journal of Occupational Psychology, 78, 553-572.

Margolis, S. L., \& Hansen, C. D. (2002). A model for organizational identity: exploring the path to sustainability during change. Human Resource Development Review, 1(3), 277-303.

Martin, G. (2007). Employer branding - time for some long and 'hard' reflections?. Chartered Institute of Personnel and Development Research Insight. Retrieved from http:/www.cipd.co.uk/NR/rdonlyres/56C8377F-256B-4556-8650-8408B0E07576/0/empbrandlatfad. pdf

Martin, G., \& Hetrick, S. (2006). Corporate reputations, branding and people management: a strategic approach to HR. Amsterdam: Butterworth-Heinemann.

Martin, G., Beaumont, P., Doig, R. \& Pate, J. (2005). Branding: a new performance discourse for HR? European Management Journal, 23(1), 76-88.

Martin, G. \& Beaumont, P. B. (2003). Branding and people management: what's in a name?. Wimbledon: CIPD. 
Minchington, B. (2011a). Employer Branding Without Borders - A Pathway to Corporate Success. Retrieved from http://www. ere.net/2011/07/05/employer-branding-without-borders-a-pathway-to-corporate-success/?utm_source=ERE + Mediaandutm_ campaign=f0861c62dc-ERE-Daily-Branding-Without-Bordersandutm_medium=email

Minchington, B. (2011b). Building employer brand equity. Retrieved from http://www.brettminchington.com/free-resources/ strategy/112-build-employer-brand-equity.html

Minchington, B. (2012). 12 Employer branding best practices to focus on in 2012. Retrieved from http://www.brettminchington.com/ free-resources/trends/132-12-employer-branding-best-practices-to-focus-on-in-2012.html

Moroko, L., \& Uncles, M. D. (2008). Characteristics of successful employer brands. Journal of Brand Management, 16(3), 160-175.

Moroko, L., \& Uncles, M. D. (2009). Employer branding and market segmentation. Journal of Brand Management, 17(3), 181-196.

Mosley, R. (2007). Customer experience, organizational culture and the employer brand. Brand Management, 15(2), $123-134$.

Nadler, J. T., Cundiff, N. L., Lowery, M. R., \& Jackson, S. (2010). Perceptions of organizational attractiveness: the differential relationships of various work schedule flexibility programs. Management Research Review, Vol. 33 Iss: 9, pp.865 - 876.

Prakapavičiūtè, J.; Korsakienè, R. 2016. The investigation of human capital and investments into human capital: Lithuania in the context of the EU, Entrepreneurship and Sustainability Issues 3(4): 350-367. http://dx.doi.org/10.9770/jesi.2016.3.4(4)

Puusa, A., Tolvanen, U. (2006). Organizational Identity and Trust. Electronic Journal of Business Ethics and Organization Studies, 11(2), pp. 29-33.

Raudeliūnienė, J.; Stadnik, B.; Kindarytė, R. 2016. Knowledge appliance process: theoretical and practical evaluation aspects, Entrepreneurship and Sustainability Issues 3(4): 368-379. http://dx.doi.org/10.9770/jesi.2016.3.4(5)

Riel, C. B., \& Balmer, J. M. (1997). Corporate Identity: The Concept, Its Measurement And Management. European Journal of Marketing, 31(5/6), 340-355.

Rosethorn, H. and Mensink, J. (2007). Employer branding - more than just a fashion statement?. Employer branding: the latest fad or the future for HR? London: CIPD.

Sartain, L. (2005). Branding from the inside out at Yahoo!: HR's role as brand builder. Human Resource Management, 44(1), 89-93.

Sartain, L., \& Schumann, M. (2006). Brand from the inside: eight essentials to emotionally connect your employees to your business. San Francisco, CA: Jossey-Bass.

Schreurs, B., Druart, C., Proost, K., \& Witte, K. D. (2009). Symbolic attributes and organizational attractiveness: the moderating effects of applicant personality. International Journal of Selection and Assessment, 17(1), 35-46.

Shahzad, K., Gul, A., Khan, K. \& Zafar, R. (2011). Relationship between perceived employer branding and intention to apply: evidence from Pakistan. European Journal of Social Sciences, 18 (3), 462-467.

Simmons, J. A. (2009). "Both sides now": aligning external and internal branding for a socially responsible era. Marketing Intelligence \& Planning, 27(5), 681-697.

Sivertzen, A., Nilsen, E. R., \& Olafsen, A. H. (2013). Employer branding: employer attractiveness and the use of social media. Journal of Product \& Brand Management, 22(7), 473-483.

Sullivan, J. (2004). The 8 Components of a Successful Employment Brand. ere.net. Retrieved from http://www.ere.net/2004/02/23/the8-elements-of-a-successful-employment-brand/

The Conference Board (2001). Engaging Employees through Your Brand. Research Report 1288-01-RR. New York, NY: Charles Schwab.

Turban, D. B. (2001). Organizational Attractiveness as an Employer on College Campuses: An Examination of the Applicant Population. Journal of Vocational Behavior, 58(2), 293-312.

Turban, D. B., \& Greening, D. W. (1997). Corporate Social Performance and Organizational Attractiveness to Prospective Employees. Academy of Management Journal, 40(3), 658-672.

VersantWorks (n.d.). Activating the Employer Brand. Retrieved from http://www.versantsolutions.com/uploadedFiles/_media/_pdf/Employer_Branding.pdf 
Wilden, R., Gudergan, S., \& Lings, I. (2010). Employer branding: strategic implications for staff recruitment. Journal of Marketing Management, 26(1-2), 56-73.

Yu, K. Y. T. (2014). Person-organization fit effects on organizational attraction: A test of an expectations-based model. Organizational Behavior and Human Decision Processes, 124, 75-94.

Zaveri, M. \& Mulye, R. (2010). Country of origin effect and employer attractiveness: A missing link“, in Paul Ballantine and Dr Jorg Finsterwalder (ed.) Proceedings of the Australian and New Zealand Marketing Academy Conference 2010, Christchurch, New Zealand, 29 November - 1 December 2010.

Rita BENDARAVIČIENE். Dean of the Faculty of Economics and Management, Assoc. Professor at the Department of Management at Vytautas Magnus University, Kaunas, Lithuania. Research interests include employer branding, organizational attractiveness, employee motivation, engagement, generational differences, and organizational ecology dynamics. Teaches Social and Marketing Research, Organizational Communication, Strategic Management. 